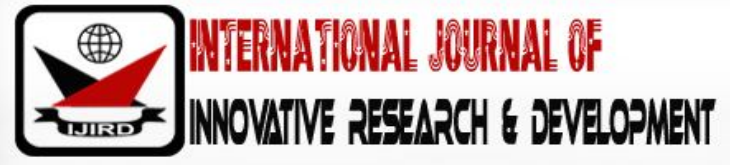

ISSN 2278 - 0211 (Online)

\section{Bridging Access to Justice, Development and Justice ability of Economic, Social and Cultural Rights in a Developing Economy: Nigeria in View}

\begin{tabular}{|c|}
\hline Eseni A. Udu \\
Lecturer, Ebonyi State University, Nigeria \\
\hline
\end{tabular}

\begin{abstract}
:
Justice ability as a concept is the capability of being decided by a court. It imports a just or legal right of a person to maintain an action in court and be heard on that cause by a court of competent jurisdiction. Access to justice, on the other part, is the legal rights of an aggrieved party to go to court and question the offending act of either a private person or government agency. Thus, both the concept of justice ability and access to justice implies the remedy available to an aggrieved person in a dispute between him and another to invoke the intervention of the court to enthrone justice. The court of law is a court of justice, and anybody coming before it must have a just cause. This paper is aimed at appraising the justice ability or otherwise of economic, social and cultural (ESC) rights. It was found that ESC rights fall short of enforceability before national courts in the majority of jurisdictions of the world. This paper maintains that the non-justice ability of ESC rights is a brazen denial of the right of access to justice in the event breach of these rights. This paper therefore advocates for the expansion of the justice ability of ESC rights in line with the improving economic resources of varying jurisdictions. The genre of rights branded economic, social and cultural rights are the rights that condition the worth of the human person, and therefore remain in dispensability for the wellbeing of every individual.
\end{abstract}

Keywords: Rights, access to justice, development, economic, social, cultural and justice ability

\section{Introduction}

Justice ability is often seen as a complex concept replete with numerous arcane rules and exceptions. In a nutshell, it connotes the susceptibility to judicial inquiry and scrutiny. ${ }^{1}$ Courts however applied it on an adhoc basis, inconsistently choosing to emphasize one element of its tests over another. ${ }^{2}$ This fact has led legal scholars to despair of ever reaching a unified analysis of justice ability. Some have taken the cynical view that courts will find a case justice able when they want to hear it and refuse to find it justice able when they do not wish to hear it. Recall that justice ability means proper examination in court of justice and it depends on whether there is a right or obligation known to the law to be protected or enforced. ${ }^{3}$ If one single issue has dominated the debate over economic, social and cultural rights, it is the question of whether those rights are justice able at the national level. Justice ability means proper examination in court of justice and it depends on whether there is a right or obligation known to law to be protected or enforced. ${ }^{4}$ In Nigeria, the question of justice ability of the provisions of Chapter IV of the Constitution is not in issue. The constitution provides that any person who alleges that any of the provisions of Chapter IV has been, is being or likely to be contravened in any state in relation to him may apply to the High Court in that state for redress. ${ }^{5}$ This provision covers cases not only of actual violations but also cases of anticipated breach of right. ${ }^{6}$ This paper puts in clearer perspective the meaning and concept of justice ability with a view to setting out the propriety or otherwise of the debate over the enforcement of economic, social and cultural rights.

\footnotetext{
${ }^{1}$ Nwoha, S.A., Principles of Nigerian Law and Real Practice, Vol. I. (Enugu: John Jacobs Classic Publishers Ltd, (2006) p. 18.

2Barton, T., 'Justice ability: 'A Theory of Judicial Problem Solving' Bolston College Law Review, Volume XXIV, May 1993, Number 3, p. 21.

${ }^{3}$ Ladan, M.T., Introduction to International Human Rights and Humanitarian Laws (Zaria: Ahmadu Bello University Press, 1999) p.71; See also Adamu v. Borno State (1996) 8 [NWLR) 203.

${ }^{4}$ Ladan, M.T., op. cit, note 3 p.71.

5 The Constitution of the Federal Republic of Nigeria, 1999 (as amended), section 46.

${ }^{6}$ Okogie v A.G. Lagos State (1981) I NCLR 218. It was agreed that s. 46(1) permits a plaintiff to commence proceeding if he fears that his right is likely to get trampled upon. See also Omotesho, A.O. and Bawa, A.,Issues on Constitutional Law (Lagos: Bold Technology and Systems (Nig.) Ltd, 2001$)$ p. 58.
} 


\section{The Concept Justice ability}

The concept of justice ability just as other legal concepts does not have any definite definition. Thus, different authors and scholars have defined the concept according to their orientation. According to Bryan, it is the quality or state of being appropriate or suitable for review by a court.7 Arambulo remarks that the term 'justice ability' is generally understood to refer to a right's faculty to be subjected to the scrutiny of a court of law or another (quasi) judicial entity. A right in a concrete set of circumstances and in due consideration can result in further determination of this right's significance. ${ }^{8}$ Scott and Macklem submit that by the term 'justice ability', we mean, in broad outline, the extent to which a matter is suitable for judicial determination whether or not a person's right has been violated or whether the state has failed to meet a constitutionally recognized obligation to respect, protect or fulfill a person's right. ${ }^{9}$

Scott and Macklem remarked further that, 'justice ability' is a deceptive term because its legalistic tone can convey the impression that what is or is not justice able inheres in the judicial function and that it is written in stone. In fact, the reverse is true, not only is justice ability variable from context to context, but its context varies over time. Justice ability is a contingent and fluid notion dependent on various assumptions concerning the role of the judiciary in a given place at a given time as well as on its changing character and evolving capability. 10

Justice ability is concerned with the limits of legal issues over which a court can exercise its judicial authority. ${ }^{11}$ It includes, but not limited to, the legal concept of standing, which is used to determine if the party bringing the suit is a party appropriate to establishing whether an actual adversarial issue exists. ${ }^{12}$ Essentially, justice ability seeks to address whether a court possesses the ability to provide adequate resolution of the dispute. Where a court feels it cannot offer such a final determination, the matter is not justice able. It is a criterion used by the court to seize a matter for the determination of any issue. In order for an issue to be justice able before the court, all of the following conditions must be met:

- The parties must not be seeking an advisory opinion.

- There must be an actual controversy between the parties.13 This means that the parties cannot agree to a lawsuit where all parties seek the same particular judgments from the court (known as a collusive suit or friendly suit); rather, the parties must each be seeking a different outcome.

- The question must be neither unripe nor moot. ${ }^{14}$ Note however, that if the issue is likely to reoccur, yet will continually become moot before any challenge can reach a court of competent jurisdiction, courts may allow a case that is moot to be litigated.15

- The suit must not be seeking judgment upon a political question. ${ }^{16}$

The issue of non-justice ability has been recognized in various jurisdictions, including the United Kingdom where it was stated that this principle is not a matter of digression, but is inherent in the nature of the judicial process. ${ }^{17}$

It is important to note that all cases brought before the appellate courts are accepted for their reviews. The constitution, for instance, oust the jurisdiction of the courts to hearing certain cases or controversies. Before agreeing to hear a case, a court shall first examine its justice ability. This preliminary review does not address the actual merits of the case, but instead a number of tests based on judicial doctrines are applied to ascertain the justice ability of a matter before the court, to wit:

- Whether the party suing is the proper plaintiff.

- Whether there is actual adversity between the parties.

\footnotetext{
${ }^{7}$ Garner, B.A., (ed), Black's Law Dictionary, Ninth Edition (Texas: West Publishing Co, 2009) p. 943.

${ }^{8}$ Arambulo, K., Strengthening the Supervision of the International Covenant on Economic, Social and Cultural Rights - Theoretical and Procedural Aspect, (Oxford: Intersentia-Hart Antwerp/ Groningen, 1999) p. 55.

${ }^{9}$ Scott, C. and Macklem, P., 'Constitutional Ropes of Sand, or Justice able Guarantees? Social Rights in a New South African Constitution', University of Pennsyvania Law Review, Vol.141.No.1, November 1992, p. 17.

${ }^{10}$ Ibid., note 9, p. 17.

11 May, C. and Allen, I.,Constitutional Law: National Power and Federalism, Fourth edition (New York: Mynas Pen Publishers, 2007) pp. 97-99.

${ }^{12}$ Flast v. Coben, 392 U.S. 83,100 (1968).

13Muskrat v United States, 219(U.S)346(1911).

${ }^{14}$ An unripe question is one for which there is not yet at least a threatened injury to the plaintiff, or where all available judicial alternatives have not been exhausted. A moot question is one for which the potential for an injury to occur has ceased to exist, or where the injury has been removed; Poe v Cullman, 367 U.S 499 (1961; Detunes v Ode Guard 416 U.S. 312,(1974).

15Roe v Wade, 410 U.S 113(1973).
}

16 Political questions involve matters where there is a textually demonstrable constitutional commitment of the issue to coordinate political department, and the U.S Constitution therefore, requires another branch of government to resolve questions regarding the issue. It also involves a lack of judicially discoverable and manageable standards for resolving issue as well as an impossibility of deciding it without an initial policy determination of a kind clearly for non judicial discretion. Political questions also connote an impossibility of a court undertaking independent resolution without expressing lack of respect due co-ordinate branches of government; an unusual need for unquestioning adhered to a political decision already made; or a potentiality of embarrassment from multifarious pronouncements by various departments on one question. Issues such as whether the nation is at war with another country, or whether the legislature has properly 'tried' an impeached federal officer constitutes a political question. If a case fails to meet any one of these requirements, the court cannot hear it. However, some states permit their courts to give advisory opinions on questions of law, even though there may be no actual dispute to resolve between parties. See also Nixon v United States, 506 U.S 224 (1993).

${ }^{17}$ Buttes Gas and Oil Co.v. Hammer (1982) AC 888; McGoldrick, D., The Boundaries of Justice ability', 59 International and Comparative Law Quarterly 981 (2010); See also Martyniszyn, M., (2011) 'Avoidance Techniques: State Related Defences', International Antitrust Cases, Working Paper No. 11-12. See further, Kuwait Airways Co v. Iraqi Airways, (2002) UKHL 19 where the principle was further developed. Case note: Kuwait Airways Corporations v. Iraqi Airways Company; Carothers, J.M. and Crawford, E.B.,The International and Comparative Law Quarterly, vol. 52, No 3 (July, 2003 ), pp. 761 - 774. 
- Whether the issue for determination is substantive and not of frivolities.

- Whether the case is statute barred (the timing of the case). ${ }^{18}$

For a case to be heard, it must survive this review. In practice, courts have wide latitude to apply these tests. They commonly emphasize whichever factors they deem important. This irregularity has made the analysis of justice ability a difficult task for lawyers, scholars and the courts themselves. Behind the test for justice ability are a number of legal doctrines. The Court has declared that the doctrine has both constitutional and prudential components, especially based on what the courts consider prudent judicial administration. ${ }^{19}$ The distinction has important consequences for the limits of judicial power. The legislature, for instance, has the authority to pass laws that override only the prudential limits of judicial review. It cannot, however, pass laws that override constitutional limits.20

Among the most complex justice ability doctrine is 'standing' which applies strictly to the plaintiff. Standing focuses on the party, not on the issues he wishes to have adjudicated. ${ }^{21} \mathrm{~A}$ claimant is said to have standing if he is found by the court to have the right to a trial. In order to reach such a determination, the court uses several general rules. These rules require that the claimant must have suffered an actual or threatened injury; that the case alleges a sufficient connection (or nexus) between the injury and the defendant's action; that the injury can be redressed by a favorable decision; and that the plaintiff neither brings a general grievance nor represents a third party. The question of justice ability notably, emphasizes the legal relationship of the parties in the case as well as the substance of their dispute.22

Moreover, the issue in controversy must be real and substantial, and therefore more than mere generalized interests common to the public at large. A related rule forbids the courts to issue advisory opinion. The courts must decline to rule on merely hypothetical or abstract questions. In addition, they are restricted from taking cases that address purely political questions, which are beyond the judicial purview. ${ }^{23}$

The fourth concern of tests for justice ability, the timing of the case, is evaluated under the concepts of 'ripeness' and 'mootness'. The 'ripeness doctrine' holds that a case is justice able if the harm asserted has matured sufficiently to warrant judicial intervention. ${ }^{24}$ The 'mootness doctrine' prevents a court from addressing issues that are hypothetical or dead. A case may become moot because of a change in law or in the status of the litigants. Most commonly, it is held to be moot because the court is presented with a fact or event that renders the alleged wrong no longer existent, for example, the US Supreme Court case of 1952 challenging Bible reading in the public schools. The child behind the suit had already graduated and the parents and taxpayers who brought the suit could show no financial injury. ${ }^{25}$ However, the court did agree to hear the landmark Abortion case, ${ }^{26}$ even though the plaintiff was no longer pregnant. The court gave as its reason the length of a woman's gestation period (nine months), which is too short to permit appellate review.

Adding his voice, Nwabueze opined that a matter can be justice able if it is liable to be tried by a judicially enforceable court and such a matter is one affecting the legal rights of a person. According to him, justice ability is essential to the conception of judicial power, or the power to give a binding decision or determination. This judicial power is exercised only in respect of justice able matters. ${ }^{27}$ In the words of Nwabueze, the necessary requirements for a matter to be justice able are:

\subsection{The Nature of the Dispute}

The dispute must be of a legal nature for it to be justice able. As such, it should concern a person's legal rights or relations before the court can determine it. Such legal rights may be personal or proprietary in nature. Hence, an issue will not be justice able if there is no recognized legal right. As explained by Nwabueze, social rights may not be enough in this regard as nobody has a special right over and above others in a name, apart from trade name. As such, anybody can call himself by any name he chooses despite the fact that the name may be a patrimony of a particular family..$^{28}$

Besides, a law may make a matter non-justice able. For instance, the 1999 Constitution of the Federal Republic of Nigeria specifically made all matters contained in its Chapter II, dealing with Fundamental Objectives and Directive Principles of State Policy, non-justice able or unenforceable by the courts. ${ }^{29}$ Section 6, sub-section 6 (c) provide that no court shall entertain:

\footnotetext{
18 Nwoha, S.A., Principles of Nigerian Law and Real Practice, op. cit., note 1, p. 18.

19Ibid., note 18.

20Ibid. note 19.

${ }^{21}$ Flast v Coh

en, 392 U.S. 83, 888 S.Ct (1942), 20 L.ed 2d 947.

22Ibid., note 21.

23Flast v Cohen, 392 U.S. 83, 888 S.Ct (1942), 20 L.ed 2d 947.

${ }^{24}$ Warth v Seldin, 422 U.S. 490, 95 S.C.E 2197, 45 led. 2 d 343 (1975).

${ }^{25}$ Doremus v Board of Education, 342 U.S. 429, 72 S.Ct. 394, 96.L. Ed. 475

${ }^{26}$ Roe v Wade, 410 U.S113, 93 S.Ct. 705, 35 L. Ed. 2d 147 (1973).

${ }^{27}$ Nwabueze, B.O., Judicialism in Common Wealth Africa (London: C. Horst $\beta$ Co, 1977) p.3. See also A.G. Ondo State v A.G Federation (2005) 9 N.W.L.R. (Pt 772) 272-276.

${ }^{28}$ Cowley v Cowley (1901) A.C P. 450 (H. L).

29 Odike, E.A.,Principles and Practice of Nigerian Law, Vol. I (Abakaliki: Willy Rose \& Appleseed Publishing Co., 2009 ). p. 84.
} 
Any issue or question as to whether any act or omission by any authority or person or as to whether any law or a judicial decision, is in conformity with the Fundamental Objectives and Directives Principle of State Policy set out in chapter II of this constitution ${ }^{30}$

Chapter II of the 1999 constitution mainly contains the fundamental obligations of government: political objective, economic objectives, social objectives, educational objectives, foreign policy objectives, environmental objectives, directives on Nigerian culture, obligation of the mass media, national ethics, and duties of the citizen. The above constitutional provision not being enforceable rights by virtue of the ouster clause are, at best, mere exhortations or platitudes, which government and its arms are enjoined as a matter of constitutional responsibility to conform to, observe and apply in their dealings. ${ }^{31}$

\subsection{Legal Rights}

Another attribute of a justice able matter is that apart from being a legal issue, a person alleging the violation of his perceived rights must show that the violation has injuriously affected his legal rights or threatened it.

\subsection{Existing Judicial Remedy}

The third requirement for a matter to be justice able is that there should be an existing judicial remedy for the redress of the wrong complained of. As a matter of legal principle, where there is a right, there is a remedy. This is a legal reality aptly captured in a Latin maxim - Ubi jus ibiremedium. This is notwithstanding the fact that constitutional conventions are often non-justice able. Finally, it should be noted that a justice able issue does not always require opposing parties. For instance, the determination of a succession case by the court may be commenced by an application of a person seeking grant of letter of administration.

Accordingly, the concept of justice ability has been developed to identify appropriate occasions for judicial action. The central concepts often are elaborated into more specific categories of justice ability viz: advisory opinions, feigned and conclusive cases, standing, ripeness, mootness, political questions, and administrative questions. Let us look at these categories closely: 32

\subsection{The Doctrine of Political Question}

The claim that a political question is 'non-justice able' leads to the result by which the court does not see itself as authorized to intervene in the issue brought before it. In essence, since the political nature of the question renders it nonjustice able, the court is inexorably led to refuse to adjudicate, for in its view it lacks jurisdiction. ${ }^{3}$ In Baker v Carr, ${ }^{34}$ the court in determining whether a dispute constitute a non-justice able political question, relied on a test namely: (a) a textually demonstrable constitutional commitment of the issue to a coordinate political department or (b) a lack of judicially discoverable and manageable standards for resolving it; or (c) the impossibility of deciding without an initial policy determination, or $(\mathrm{d})$ the impossibility of a court understanding independent resolution without expressing lack of the respect due coordinate branches of government; or (e) an unusual need for unquestioning adherence to a political decision already made; or (f) the potentiality of embarrassment from multi-various pronouncements by various departments on one question.

In applying the criteria enunciated in Barker v Carr, the court in Nixon v United States, ${ }^{35}$ took remedial consideration into account in holding that disputes under particular constitutional provisions present non-justice able political questions. In its holding, the court said that responsibility for determining the requirements of an impeachment trial was 'textually demonstrably committed' to the senate not the judiciary.

Also, the decision in Gilligan v. Morgan, ${ }^{36}$ on the doctrine of political questions is instructive. The case arose from an incident in which members of the Ohio National Guard killed a number of civilians at Kent State University. Members of the Kent State Students government sought an injunction ordering changes in the Guard's supervision and organization. However, the court invoked the political question doctrine. Indeed, the court found all of the Baker v. Carrcriteria to be satisfactory. Although it emphasized the absence of judicially manageable standards, it noted that it is difficult to conceive of an area of governmental activity in which the courts have less competence.

\subsection{The Doctrine of Standing}

Standing focuses on whether a plaintiff is the right person to bring a given issue before the court. This is what makes standing jurisdictional, that is, the inquiry is not about the existence of a wrong, but whether the court can respond at the request of this plaintiff. The standing doctrine has three components namely: whether the plaintiff alleges an 'injury in fact',

\footnotetext{
30 Constitution of the Federal Republic of Nigeria, 1999.

${ }^{31}$ Ibid., note 30 , section 6.

32 Wright, C.A., et al, Federal Practice and Procedure, No. 3529, 2nd ed. (1984) pp. 278-279.

${ }^{33}$ Navot, S.,'Political Questions in the Court: Is 'Judicial Self-Restraint' a Better Alternative than a Non-Justice able Approach?", VII World Congress of the International Association of Constitutional Law Rethink, the Boundaries of Constitutional Law", Workshop: Judicial Review of Politically Sensitive Questions. p. 22 .

34369 4.5. 186,217 (1962).

35506 U.S..224, 229, 236 (1993).

36413 U.S. 1 (1973).
} 
whether that alleged injury 'fairly can be traced to the challenged action' and finally, whether a favourable ruling would probably end the injury. ${ }^{37}$

Beyond this constitutional 'core' of standing are 'prudential' standing rules invented by the courts themselves.38 For example, in the case of McGowan v Maryland, 39 the court noted that 'the most important prudential rule prevents litigants from asserting the rights of others (jus tertii)". In the case of Friends of the Earth v. Laid Environmental Services, ${ }^{40}$ the court held that the doctrine of standing rests on three requirements. These are that a plaintiff must show: (i) he has suffered an 'injury in fact' that is: (a) concrete and particularized and (b) actual or imminent, not conjectural or hypothetical, (ii) the injury is fairly traceable to the challenged action of the defendant, and (iii) it is likely, as opposed to merely speculative, that the injury will be redressed by a favourable decision.

\subsection{Mootness Doctrine}

The mootness doctrine is to the extent that a case must meet the mootness standard for it to be justice able. In essence, the case must present a current problem that has to be resolved. For example, ruling in the Defunis v. Odegaard ${ }^{41}$ case $^{2}$ in 1974, the court held that a student could not challenge allegedly discriminatory law school admissions procedures after he had already been admitted to the law school, and was about to graduate.

The mootness doctrine makes justice ability depend on judgments about the appropriateness or acceptability of particular remedies after the cessation of conduct that once caused injury. In City of Erie v Pap's A.M., ${ }^{42}$ after a state court enjoined enforcement of Erie's anti-nudity ordinance, the city sought Supreme Court review. By the time the case reached the court, the nude-dancing establishment that brought the challenge had closed, but the court upheld justice ability nonetheless. In finding the case not too moot, the court cited a number of factors, prominently, including the city's continuing inability to enforce its ordinance due to the injunction issued by the state court. According to the court's majority, the interest in relieving the city from that prohibition, if it were constitutionally unjustified, supported a holding that the case was not moot, despite the absence of any continuing personal stake on the part of the plaintiff.

\subsection{Ripeness Doctrine}

Court will only adjudicate case that passes the ripeness test. That is a case that presents an actual and substantial threat to individual rights or other constitutional provisions. For example, the court decided in United Public Workers v. Mitchell, ${ }^{43}$ that a group of Federal Workers could not block enforcement of a law that created only the possibility of a law to their first Amendment Rights.

Concerns about remedies also exert significant influence in the shaping and application of ripeness doctrine. In a now classic formulation in Abbott Laboratories v. Gardner, ${ }^{44}$ Justice Harlan wrote that the 'basic rationale of 'ripeness doctrine' is to prevent the courts through avoidance of premature adjudication, from entangling themselves in abstract disagreement over administrative policies. He added that the problem is best seen in a two-fold aspect, requiring us to evaluate both the fitness of the parties of withholding court consideration. 45

\subsection{Advisory Opinion}

If a case does fall within the court's jurisdiction, it must also be justice able. This means that it must raise questions that are appropriate for the court to answer. When the judicial branch is asked to give advice, subject to review by another branch or prior to its having acted, courts occupy a subordinate posture. This is not acceptable to the judiciary.

In Harburn's case, 46 it was held that for courts to issue opinion that could be 'revised and controlled by the legislature and by the officer in the executive department' would be radically inconsistent with the independence of that judicial power which is vested in the courts. This is why issues that may give rise to advisory opinions are not justice able. ${ }^{47}$

Having defined the concept of justice ability as proffered by different authors, and also reviewed some justice ability doctrines as generally applied by the courts, it is apposite to relate the concept with the argument as regard whether the economic, social and cultural rights (ESCR) are justice able.

Arguments in the debate of the non-justice ability raised in opposition and for judicial enforcement of social rights are manifold. In the main, these arguments implicate the special nature of economic, social and cultural rights, and the institutional limitations of court to make adjudication of these categories of rights. In addition, debates over the justice ability

\footnotetext{
37Valley Forge Christian Coll. v Ams. United for Separation of Church and State, 454 U.S. 464, 472 (1982).

${ }^{38}$ Kontorovich, E., 'What Starting is Good for: The Doctrine and the Critics', Virginia Law Review, (Vol.93), p.1663.

39366 U.S. 420 (1961).

40528 U.S. 167, 180-81 (2000).

41416 U.S. 312 (1974).

42529 U.S.277 (2000).

43330 U.S. 75 (1947).

44387 U.S. 136, 148 (1967), 149.

45Ibid., note 44 , p. 149.

462 U.S. (2 Dall.) 409, 411-13 (1792).

47 Fyanka, K.T., TheJustice ability of Social Rights: Myth or Reality?' Human Right Review, Vol.1. No.1. (2010),pp. 437-444.
} 
of economic, social and cultural rights take into consideration the basic democratic principle that the majority will should prevail in the fashioning of law and policy. This principle is driven by the doctrine of separation of powers manifested in democratic government namely, that the legislature makes the law, the executive implements the law, and the judiciary applies and enforces the law.48

Kurland noted as follows:

Separation of powers... encompasses the notion that there are fundamental differences in governmental functions

- frequently but not universally denoted as legislative, executive, and judicial which must be maintained as

separate and distinct, each to operate in the realm assigned to it. 49

Accordingly, the enactment of a constitutional bill of rights relating to economic, social and cultural rights to be interpreted and enforced by the judiciary represents a fundamental restraint on this understanding of democracy. According to proponents, certain matters will be taken away from majoritarian rule and placed within the exclusive interpretative province of the judiciary. Yet, traditional separation of powers requires that in performing the interpretative function, the judiciary is not to intrude on the fundamental function assigned to other branches of government. This is the starting point for many of the arguments against or for the inclusion of economic, social and cultural rights in a written constitution enforceable by the judiciary. ${ }^{50}$

In Nigeria for instance, the economic, social and cultural rights are codified in chapter II of the constitution and tagged 'Fundamental Objectives and Directives Principles of State Policy'. Regrettably, they are deemed mere aspirations for the government to direct its policies towards the realization of the noble ideals and succinctly they are non-justice able. However, these rights are intended to carry out the objectives set out in the preamble of the constitution and to establish an egalitarian social order informed by political, social and economic justice and ensuring the dignity of the individual.51

Having discussed the meaning of justice ability in the preceding heading, little will be said on the concept in this regard, while effort will be made to explain the concept of access to justice, and how the issues of justice ability have hampered its success in the enforcement of economic, social and cultural rights in many jurisdictions, particularly Nigeria.

The court of law is a court of justice, and anybody coming before it must have a just cause. Justice ability imports a just legal right of a person to maintain an action in court and be heard on that cause by a court of competent jurisdiction. It thus means that justice ability is essential to the conception of judicial inquiry and scrutiny. ${ }^{52} \mathrm{~A}$ matter is justice able if it is liable to be tried by a judicially enforceable court and the matter is one affecting the legal rights of a person. According to Nwabueze,53justice ability is essential to the conception of the judicial power, or the power to give a binding decision or determination. This judicial power is exercised only in respect of justice able matters.

Justice ability means a state of being appropriate or suitable for adjudication by the court. ${ }^{44}$ It imports a just or legal right of a person to maintain an action and be heard on that cause by a court or tribunal of competent jurisdiction. ${ }^{55}$ It concerns the limits of legal issues over which a court can exercise its judicial authority. The concept of justice ability entails that only legal issues with appropriate remedy could be adjudicated and enforced in the court. Thus, the concept, seeks to address whether a court possesses the ability to provide adequate resolution of a dispute. Where a court feels it cannot offer such a final determination, the matter is not justice able. Non-justice ability can be as a result of a bar in a statute which has ousted the jurisdiction of the court to entertain a particular issue and therefore making such a matter non-justice able;56or the nature of the dispute involved, for example, political, ${ }^{57}$ economic and social issues which are said to have no determinate legal rights are non-justice able.

Questions about the justice ability of economic, social and cultural rights have dogged the international human rights movement since the separation of the integrated rights in the Universal Declaration of Human Rights (UDHR) into two covenants. The International Covenant on Civil and Political Rights (ICCPR) provided for an optional complaints procedure at the time of its adoption, but none existed for the International Covenant on Economic, Social and Cultural Rights (ICESCR) for almost six decades of its existence. This differentiation in relation to the ability to bring forward individual and group claims under the two categories of rights has had a profound effect on the coherence and integrity of the international human rights system. While civil and political rights jurisprudence has been nourished by a generation of individual cases that contextualize and refine our understanding of these rights by reference to real people and their actual circumstances, ESC rights norms have

\footnotetext{
48 Fyanka, K.T.,op. cit, p. 445.

${ }^{49}$ Kurland, P.B., The Rise and Fall of the Doctrine of Separation of Power', 85 Mich.L.Rev. (1986) pp. 502-593.

50 Fyanka, K.T., op. cit., p. 445.

51 Okpara, O., (ed.), Human Rights Law and Practice in Nigeria, Vol.1 (Enugu: Changlo Limited, 2005) p. 282.

52 Nwoha, S.A., op. cit.,note 1, p. 18.

53 B.O. Nwabueze, Judicialism in Common Wealth Africa (London: C. Hursy and Co., 1977) p. 3; See also A.G Ondo State v A.G. Federation (2005) 9 N.W.L.R. (pt. 772) 272-276.

54 Garner, B.A.,Black's Law Dictionary, 9th Edition (Texas: West Publishing Co, 2009) p. 943.

55 Nwoha, S.A., op. cit., Principles of Nigeria Law and Practice, Vol. 1 (Abakaliki: WillyRose\& Appleseed Pub. Coy. 2009 ) p. 83.

56 For example section 6(6)(c) of the Constitution of the Federal Republic of Nigeria as amended, which provides that the powers of the court shall not extend to any issue or question as to whether any act or omission by any authority or person or as to law or any judicial decision is in conformity with the fundamental objective and directive principles of state policy set out under chapter two of the constitution.

57 Political question doctrine holds that some questions, in their nature are fundamentally political and legal, and that if a question is fundamentally political, then the court will refuse to hear the case. It will claim that it doesn't have the jurisdiction. And it will leave that question to some other aspect of political process to settle out. See also the US case of Marbury v Madison, 5 U.S 137 (1803).
} 
been developed at the international level largely without rights claimants. ${ }^{58}$ Over the years, several arguments have been proffered as the reason for non-justice ability of economic, social and cultural rights (ESC) rights.

First, economic, social and cultural rights have been seen by some as being too vaguely worded to allow judges to justify decisions on whether violations have occurred. Thus, while adjudicating such rights, questions may arise as to what constitutes, for example, hunger, adequate housing, or a fair wage. Second, it is uncertain. It doesn't contain immediate and enforceable rights, being mere aspiration to be attained in future. This is due to the fact that it depends on the availability of resources for it to be attained. For example, a lot of questions have been asked concerning the import of article 2(1) of the ICESCR. Thus, in the light of article 2(1), can it cogently be argued that the ICESCR articulate real rights, or does it merely set forth hortatory goals, programmatic objectives, or utopian ideals? Is it 'soft law'? How can rights or obligations that depend on the availability of scarce or unpredictable scarce resources in fact be rights or obligations in any meaning? How does one calculate the 'maximum extent of available resources' and what does 'progressive realization' mean? Can economic, social, and cultural rights ever be fully achieved? How can they best be enforced?59 It has been argued that lack of precise definition and certainty in the realization of the economic, social and cultural rights, is the major challenge and constraint to the justice ability and full implementation of the ESC rights.

However, it is our submission that most of these arguments preferred for non-justice ability of economic, social and cultural rights are misconceived. Economic, social and cultural rights, just as civil and political rights, suffer from vagueness and ambiguity. However, in the case of civil and political rights, through constant adjudication over the years, judges have been able to deal with such questions, and distill those ambiguities. Same could as well be achieved if economic, social and cultural rights are fully made justice able. Filling in the gaps in legislation is a clear function of the judiciary, not only in human rights law but in any area of law.

On the question of whether it is possible for a court to assess the progressive realization of economic, social and cultural rights, monitoring progressive realization can rely on several mechanisms, including the courts. In South Africa, courts have assessed whether the State is meeting its obligations towards progressive realization by considering whether the steps taken by the Government are reasonable. Thus, a failure by the government policy, to take into account one of the most vulnerable needs, for instance, housing policy, would suggest that the policy would not meet the test of reasonableness.

Further, decision of courts in countries from various regions of the world covering all economic, social and cultural rights demonstrate that these rights can be subject to judicial enforcement. For instance, in the Indian Supreme Court case of Municipal Council Ratlam v Vardhich and and ors, ${ }^{60}$ the case concerns a municipality that had failed to construct drains; filth and dirt had accumulated, and people could not remain in the locality due to the noxious nuisance. A magistrate passed an order, saying, 'construct a drain, but the municipality responded, 'We have no money'. It was appealed to the Supreme Court. The court held, among other things, that the 'right to life' of the person is affected; environmental pollution affects individual right to breathe fresh air, sanitary conditions are essential for the proper enjoyment of this right. Also, the case of Unnikrishnan J.P. v. State of Andhra Pradesh, ${ }^{61}$ the court declared that 'right to education is implicit in and flows from the right to life guaranteed under article 21. In other words, the right to education is concomitant to the fundamental rights enshrined in part III of the constitution. The state is under a constitutional mandate to provide educational institutions at all levels for the benefit of its citizens. The benefit of education cannot be confined to richer classes. Also instructive to this discussion is the case of ASK v Government of Bangladesh. ${ }^{62}$ The court held that the state must direct its policy towards ensuring the provision of the basic necessities of life, including shelter. Another relevant case is the South African case of Government of South Africa v Grootboon\&ors. ${ }^{63}$ Further, in the Economic Community of West African State Court of Justice case of Registered Trustee of Socio-Economic Rights Accountability Project (SERAP) v. Federal Republic of Nigeria \& Anor, ${ }^{64}$ the plaintiff filed an application against the defendants alleging the violation of the right to quality education, the right to dignity, the right of people to their wealth and natural resources and the right of people to economic and social development guaranteed by articles 1, 2, 17, 21, and 22 of the African Charter on Human and People's Rights. But before the court could go into the merits of the application, the second defendant filed a preliminary objection challenging the jurisdiction of the court to hear the matter, relying among other grounds that: the educational objective of the Federal Republic of Nigeria is provided for under section 18(1), (2) and (3) of chapter II of the 1999 Constitution and is non-justice able or enforceable and cannot be determined by the court. Overruling the objections and upholding the jurisdiction to entertain the matter, the ECOWAS Court of Justice held inter alia: that the

\footnotetext{
58 Porter, B., 'Justifiability of ESC Right to Effective Remedies: Historic Challenges and New Opportunities (Beijing: March www.socialrights.com/ document, accessed on 24th , August, 2013.

59 Dennis, I. and Stewart, D.P., Justice ability of Economic, Social, and Cultural Rights: Should There be an International Complaints Mechanism to Adjudicate the Rights to Food, Water, Housing, and Health?',American Journal of International Law, 98 A.J.I.L. 462,(July, 2004$)$ p. 6.

60 AIR 1980 SC1622. The judgment was delivered on 29th July,1980, available at: www.indiankanoon.org/ doc/ 440471, accessed on 24th August, 2013.

61 (1993) 1 SCC 645

62 Supreme Court of Bangladesh Writ No: 3034 of 1999, available at: http:// www.right-to-education.org/ node/ 682, accessed on 24th August, 2013.

63 (200) ZACC19, decided on 4, Oct., 2000. In this case, the respondents have been evicted from their informal homes situated on a private land earmarked for low-cost housing. They applied to the High Court for an order requiring the government to provide them adequate basic shelter or housing until they obtain permanent accommodation. The court held that the state was obliged to provide rudimentary shelter to children and their parents on demand if the parents were unable to shelter their children.

${ }^{64}$ Suit No. ECW/ CCJ/ APP/ 0808, delivered on 27th Oct, 2009, available online @

http:// www.courts.com.ecowasccj/ eng/ decisions/ 2009.10.27SERAPVNigeria.htm, accessed on 24th August, 2013.
} 
court is empowered to apply the African Charter being a treaty of members of African Union and article 17 guarantees right to education. It is a trite law that the rights guaranteed under the African Charter are justice able before this court. Therefore, since the application of the plaintiff was made pursuant to the provision of the African Charter and not under chapter II of the Constitution of the Federal Republic of Nigeria 1999, second defendant's contention that the right to education is not justice able as it falls within the directive principles of state policy cannot hold.

Suffice it to say that in Nigeria, even though section 6(6)(c) of the Constitution rendered chapter II of the same constitution non-justice able, a perusal of the decisions of the Nigerian courts available reveal that economic, social and cultural rights are enforceable in Nigeria. So, notwithstanding that the Fundamental Objectives and Directive Principles of State Policy are deemed non-justice able, the African Commission has rightly noted that civil and political rights cannot be disassociated from economic, social and cultural rights in their conception as well as universality and that, the satisfaction of economic, social and cultural rights is a guarantee for the enjoyment of civil and political rights. ${ }^{65}$ Hence, in Odafe\&ors v. Attorney-General of the Federation, ${ }^{66}$ socio-economic rights of the prison inmates to medical care were upheld by the Federal High Court. According to the court par Nwodo J (as she then was):

The government of this country has incorporated the African Charter on Human and People's Rights by means of the African Charter on Human and People's Rights (Ratification and Enforcement) Act, Cap10 LFN 2004 as part of the law of this country. The Court of Appeal in Ubani v Director of SSS (1999) 11 NWLR pt. 129 held that the African Charter is applicable in this country. The Charter entrenched the socio-economic rights of person. The court is enjoined to ensure the observance of these. A dispute concerning socio-economic rights such as the right to medical attention requires the court to evaluate state policies and give judgment consistent with the constitution. I therefore, appreciate the fact that economic cost of embarking on medical provision is quite high however, the statutes have to be complied with and the state has a responsibility to all the inmates in prison, regardless of the offence involved, as in the instant case where the state has wronged the applicants by not arraigning them for trial before a competent court within a reasonable time and they have been in custody for not less than two years suffering from an illness. They cannot help themselves even if they wanted to because they are detained and cannot consult their doctor.

\section{Access to Justice Vis-à-vis the Justice ability of Economic, Social and Cultural Rights}

The concept of access to justice can be better described than defined. This is because just as the concept of justice ability, different scholars and authors have defined and explained the import of the concept in their own perspective. For instance, access to justice has been defined as referring to the substantive and procedural mechanisms in a particular society designed to ensure that citizens have the opportunity to seek redress for the violation of their rights within the legal system. These mechanisms include the existing rules and procedures to be used by citizens to approach the courts for the determination of their civil rights and obligations. ${ }^{67}$

Put differently, access to justice refers to the administrative remedies and procedures available to a natural or juristic person aggrieved or likely to be aggrieved by an issue. It is a fair and equitable legal framework that protects human rights and delivery of justice. In other words, it simply means people in need of help find effective solutions from accessible, affordable and comprehensive justice systems, which dispense justice fairly, speedily and without discrimination, fear or favour and has a greater role for alternative dispute resolution. 68

The concept of access to justice which is a very important human right is an integral part of the rule of law. Critically, the rule of law was limited to the protection of individual's political and civil rights. Later, the concept was expanded by the efforts of international movements, beginning with the Universal Declaration of Human Rights adopted by the United Nations in 1948, and followed by the European Convention on Human Rights signed in Rome in 1950. More attention was paid not just to equality before the law but also to equal access to the law. In other words, the principle of equal access to the law and equal protection of the law becomes an essential ingredient of the rule of law, for the declaration of human rights in the constitution or their theoretical recognition in law will be rendered worthless if the aggrieved party is not able to secure adequate legal representation.

The notion of access to justice has also been defined as the right of every individual to require the state to provide a means of dispute resolution that is equally accessible and socially just. 69 This definition goes to substance and forms and

\footnotetext{
65 The preamble to the African Charter on Human and People's Rights.

66 (2004)AHRLR 205, at 211; (2005) CHR 309, at 323-324; Falana, F.Fundamental Rights Enforcement in Nigeria, Second Edition (Lagos: Legaltext Publishing Company Ltd, 2010) p. 17.

${ }^{67}$ Azinge, E. and Owasanoye, B., eds., Rule of Law and Good Governance (Lagos: Nigerian Institute of Advanced Legal Studies, 2009) p. 376. See also 'Access to Justice and Human Rights Protection in Nigeria: Problems and Prospects', in Sur, Rev. Int. Directors Human, Vol.2 No. Sao Paulo Dec. 2005, available at: http:/ / www.scielo.br/ scielo.php?scrip=sciarttext\&piq, accessed 12 August 2014.

${ }^{68}$ Ladan, M.T., 'Access to Justice and the Justice Sector Reform in Nigeria', a paper presented at the First International Conference on the State of Affairs of Africa, Organized by the International Institute for Justice and Development (IIJD), Boston, Massachusetts, USA. Oct.26-28, 2006, available at: http:/ / iijd.org.PDF\%20files/ MuhamedTawfiqLadan Justice Sector Rector Nigeria,_Pdf, last accessed 11 February 2014.

69 Cappelletti, M. and Garth, R. (eds.), 'Access to Justice: A World Survey' (1978), Vol. 1 Milan, GuilfreEditore, D.A., at 6.
} 
requires not only affordable procedures but also the administration of the law based on social justice principles that takes into account the social, cultural and economic disadvantage of litigants. ${ }^{70}$

The development of the nation is measured largely by the availability of institutional and legal framework for protection of the human rights inbuilt to its working system and the level of enforcement and practical enjoyment of such right by the people. Thus, the importance of access to justice cannot be overemphasized. Access to justice ensures preservation of human rights, which is the cornerstone of the rule of law. Through access to justice, it is possible for the courts to perform their traditional role which is interpretation and application of the constitution, the laws of the federation and the states, in justice able matters between private people. ${ }^{71}$ Thus, access to justice furthers the development of the society. Whenever the court is given the opportunity to adjudicate over a matter, the law and indeed the society, graduate to decency, decorum and civilization.

The effectiveness of a country's judicial system can be measured by the efficiency of its access to justice. Access to justice implies the delivery of justice. It has thus been said that the down way to justice delivery is strict adherence to statutes, laws, rules, regulations and constitutional provisions in relation to constitutionally guaranteed rights including the timely intervention of the judiciary in cases of clear breach of guaranteed rights or cases of justice. ${ }^{72}$

The interrelatedness and interdependence of human rights are stressed by human rights instruments and the question of justice ability at municipal level always posed problem. For instance, the economic, social and cultural rights are enshrined in the Universal Declaration of Human Rights and in various treaties, including the International Covenant on Economic, Social and Cultural Rights. They are recognized in the national laws of many countries, yet millions of people are denied these rights on daily basis. The reason is not far-fetched; in many countries, citizens have often been denied access to justice through the use of non-justice able clauses.

The question of justice ability rather lies in the enforcement of chapter II of the constitution. The provision of section 6(6)(c) of the Constitution renders the fundamental objectives and directive principles non-justice able. It provides that the judicial powers shall not, except as otherwise provided by the constitution, extend to any issue or question as to whether any act or omission by any authority or person or as to whether any law or any judicial decision is in conformity with the fundamental objectives and directive principles of state policy set out in chapter II of the constitution.

It has been noted that the fundamental objectives and directive principles of state policy in chapter II of the constitution embodies the economic, social and cultural rights.73 It follows therefore that the provision of s. 6 (6) (c) of the Constitution, has completely insulated the directives and objectives from judicial review. ${ }^{74}$ It goes without saying that, this is a total denial of access to justice to citizens, whose economic, social and cultural rights are being infringed on daily basis without redress.

The hunger for justice is as fundamental as the craving for life, for justice breeds peace and peace protects and promotes life. In the absence of justice, life is meaningless. A person whose right is infringed upon but has no access to justice to redress the wrong done to him tends towards a life of helplessness. But sometimes inaccessibility of justice may lead to violent self-help by one who refuses to watch helplessly while one's rights are trampled upon. Throughout history, denial of justice has led to revolutions and wars, be it national or international. On a personal level, people have killed or maimed or injured one another as a result of perceived denial of justice. It is against this background that civilized governments the world over makes laws that will enable the people have access to justice. It is on this basis that the National Assembly should, in the amendment of the constitution include or make social and economic rights justice able by transferring them to fundamental rights so that we can hold the Government accountable for failure to put the resources allocated for realization of these rights into effective use. The usual question is: Of what use is it to the citizen for the constitution to provide for a 'right' when such right is non-justice able?

Undoubtedly, human rights will be meaningless if we cannot enforce its breaches. It is often said that a right, which cannot be enforced, is not right at all. Diplock, L.J. in the case of Yaundoo v A.G. of Guyana, ${ }^{75}$ stated that the question of procedure and access to court are imperative. While civil and criminal justice is very important to the people, every citizen's right has to be reorganized and translated into actual judicial remedies. Denying this right would lead to erosion and denuding the real value of our society.

It is submitted that in view of the inexplicable reluctance of the state to comply with the provisions of chapter II of the Constitution, and in the absence of any provision of the Constitution categorically making it justice able as it is presently the case in India, the time has come for Nigerian Courts to borrow a leaf from India where an active judiciary has compelled the government to enforce certain aspects of the Fundamental Objectives and Directive Principles of State policy. Suffice it to say that chapter II of the 1999 Constitution of the Federal Republic of Nigeria is structured in the pattern of Part III of the Indian Constitution. There is no clear difference between the two constitutions in respect of economic, social and cultural rights

\footnotetext{
70Ibid., note 69, p. 6 .

${ }^{71}$ Nwabueze, B.O., Federalism in Nigeria under the Presidential Constitution, (London: Sweet and Maxwell), p.164.

72 Quakers, N.I., 'Litigation as Machinery for Political, Economic and Social Reform in Nigeria'. A Paper presented at the Symposium on Public Interest Lawyering organised by Access to Justice on the 7th of August 2009, Available at: http: www.Lexprimus.com.publication,/ accessed on 11/ $02 / 11$.

73 Udu, E.A.,Human Rights in Africa (Lagos: Mbeyi and Associate (Nig.) Ltd., 2011, p. 203.

${ }^{74}$ Omotesho, A.O. and Bawa, A.,Issues on Constitutional Law. (Lagos: Bold Technology and Systems (Nig.) Ltd, 2001). 75 (1971) A.C. 972.
} 
provisions under the head 'Fundamental Objectives and Directive Principles of State Policy'. Therefore, if the Indian judiciary could embark on such radical jurisprudence in the enforcement of economic, social and cultural rights even in the teeth of inhibiting ouster clauses, Nigerian judiciary can do much more given the improvements in the statutory recognition of ESC rights enforcement in Nigeria over and above India.

\section{The Interplay Development and Access to Justice in the Realization of ESC Rights}

We will not enjoy development without security, we will not enjoy security without development and we will not enjoy either without respect for human right'.76 Ever since the first United Nations World Conference on Human Rights, held in Teheran in 1968, the relationship between human rights and development has occupied a prominent place in the international discourse of rights. Since 1977 the debate has been pursued with increasing vigour under the rubric of the right to development.77

Human rights and development are inextricably linked. They have the same ultimate objective to improve human well-being and freedom, based on the inherent dignity and equality of all people. Human rights and development policies and strategies are mutually reinforcing and complementary. Whereas development will focus on social welfare and on economic growth, human rights established a universally accepted legal regime that conceptualizes rights in terms of 'duty bearers' and 'rights holder'. This consensual legal framework is continuously expanding and adapted to different political, social and cultural environments.

Human rights-based approach to development, hence bases on the empowerment of citizens, the demand for delivery of the rights and services which they are entitled to while at the same time developing the capacity of state to fulfill the obligations to protect, respect and promote the rights of their citizens. The strategic use of human rights in development policies is therefore a powerful tool in the strengthening of bottom up and participatory approaches to empower specifically vulnerable groups. ${ }^{78}$

The actual measure of sustainable development is the well-being of the individual. An interpretation of human rights that does not accommodate the problems posed by human poverty, want and ignorance must be anemic and otiose. The right to life includes the right to live with human dignity and all that goes with it, namely; the bare necessities of life, such as adequate nutrition, clothing and shelter and facilities for reading, freely moving about, and mixing with fellow human beings. ${ }^{79}$ It is therefore not surprising that the agencies of the United Nations have utilized every opportunity at their disposal to underscore the indivisibility of the rights.

An important achievement in establishing the relationship between human rights and development was the so-called Millennium Development Goals (MDGs). At the UN Millennium Summit in 2000, world leaders agreed upon a set of time-bound and measurable goals and targets for combating poverty, hunger, disease, illiteracy, environmental degradation and discrimination against women. These goals aim at achieving measurable progress in a number of specific fields which are considered essential for human development and severally lead to increased enjoyment of human rights, such as primary education. The goals provide a framework for development cooperation of institutions to work coherently together towards a common end. Close cooperation is imperative as a larger majority of nations can only reach the MDGs with substantial support from outside. Progress towards the MDGs is being measured on a regular basis. The MDGs led to increased emphasis on human rights-based approaches to development and poverty reduction.

Recall that the Sustainable Development Goals (SDGs) is an advancement as well as a replacement of the Millennium Development Goals (MDGs) endorsed by the Nigerian government as an embodiment of the new development agenda spanning from 2015-2030.80 Nigeria had already submitted two major reports in line with the demands for the commencement of the SDGs, to wit:

- September 2015 - End Point MDG Report, and

- The First National Report 2017 on the implementation of the SDGs in Nigeria, 2017.

This 2030 agenda comprises 17 new Sustainable Development Goals (SDGs) or Global Goals, which will guide policy and funding for the next 15 years, beginning with a historic pledge to end poverty. The Sustainable Development Goals (SDGs) otherwise known as the Global Goals, are a universal call to action to end poverty. Nigeria must therefore make positive changes, especially in the area of advancement of the justice ability of economic, social and cultural rights, in order to achieve the SDGs, come 2030.81 This is however, dependent on the available resources in Nigeria. Thus, the test for realizing economic, social and cultural rights is not necessarily justice ability but progressive realization within available resources.

Human rights-based approach deals with the substance of the development support initiatives but focuses on the way in which development is being approached. The human rights-based approach, in essence, requires that policies and institutions working on development and reduction of poverty base themselves on the obligations that emanate from the international human rights conventions, to wit: International Covenant on Civil and Political Rights(ICCPR), International

\footnotetext{
${ }^{76}$ Report of the UN Secretary-General, 'In Larger Freedom: Towards Development, Security and Human Rights for All:2005'.

77 Steiner, H.J and Alston, P.,International Human Rights in Context, (Oxford: Clarendom Press, 1996) p.1110.

${ }^{78}$ EIDHR: Democracy, Human Rights and Development, available at: http:// www.eidhr.eu/ democracy-human-right, accessed on 12 June 2014.

${ }^{79}$ Caroline v Union Territory of Delhi .I.R. 1981.

${ }^{80}$ Available at: www.ng.undp.org, accessed on 28 October, 2017.

81 Available at: www.panafrican-med-journal.com, accessed on 28 October 2017.
} 
Covenant on Economic, Social and Cultural Rights(ICESCR), Convention on the Elimination of Racial Discrimination(CERD), Convention on the Elimination of All Forms of Discrimination Against Women(CEDAW), Convention Against Torture (CAT), Convention on the Rights of the Child (CRC) and Convention on the Rights of Persons with Disability (CRPD) ${ }^{82}$

Human rights are inherent to person and belong equally to all human beings and their realization has to be carried out as a participatory, egalitarian and transparent process. Human rights instruments such as the Universal Declaration of Human Rights, provides a coherent framework for practical action at the international and domestic levels to reduce poverty. The human rights-based approach to poverty reduction upholds the principles of universality and individuality, empowerment and transparency, accountability and participation.

The United Nations Development Programme (UNDP) plays a central role with the U.N in realizing the human rightsbased approach to development. It focuses its policy, programming and capacity development support to this approach. In particular, it:

- Encourages all actors to adopt a human rights-based approach in tailoring and customizing the MDGs target to the local context.

- Focuses on the capacities of duty holders to meet their obligations to respect, protect and fulfill rights; as well as the capacities of right holders to claim their rights.

- Enhances the synergy between poverty reduction and democratic governance. Programmes for local governance, access to justice, capacity of human rights institutions, grassroots initiatives for community development and human rights education will be included among pro poverty reduction programming.

- Enhances the work of UN Treaty bodies: particularly strives to incorporate selected and relevant recommendations that result from periodic reviews into its programme development.

- Promotes and supports participatory assessment methodologies that link rights, obstacles and strengths around which poor people can secure their livelihood.

- Build in-house capacity to undertake multi-disciplinary review and analysis that maximize meaningful participation of the poor.

The human rights-based approach is a perspective and process that can lead more directly to increased enjoyment of human rights. Development processes which are traditionally technical and economically oriented are becoming increasingly focused on enjoyment of rights and promotion of values. One of the most important aspects of this approach is the increased recognition of poverty as one of the greatest barriers to the universal enjoyment of human rights. ${ }^{83}$ In short, human rightbased approach aims for sustainable outcomes by analysing and addressing the inequalities, discriminatory practices and unjust power relations which are often at the heart of development problems.

The right to development is rooted in the charter of the United Nations, the Universal Declaration of Human Rights, and the two international human rights covenants. Development and human rights are intricately linked. As such, numerous documents have explicitly acknowledged their indivisibility, including the Declaration on the Right to Development (1986), the African Charter on Human and People's Rights, the Declaration on the Rights of Indigenous Peoples (2007), the Vienna Declaration and Programme of Action (1993), and the Rio Declaration on Environment and Development (1992).

Ultimately, both development and human right movements share the same enthusiasm and motivation to promote the freedom, well-being and dignity of individuals. On the one hand, human development improves the capacities and freedoms of individuals while on the other hand, human rights provide the framework for a social arrangement that facilitates and secures capabilities and freedoms expressed by human development. Article 1 of the Declaration on the Right to Development, ${ }^{84}$ states as follows:

The right to development is an inalienable human right by virtue of which every human person and all peoples are entitled to participate in, contribute to, and enjoy economic, social, cultural and political development, in which all human rights and fundamental freedoms can be fully realized.

Moreover, the preamble of the Declaration states thus:

Development is a comprehensive economic, social, cultural and political process, which aims at the constant improvement of the well-being of the entire population and of all individuals on the basis of their active, free and meaningful participation in development and in the fair distribution of benefits resulting there from.

Article 1 identifies the human person as the beneficiary of the right to development. It imposes obligations on individual states to ensure equal and adequate access to essential resources and on the international community to promote fair development policies and effective international co-operation. 85

The right to development was reaffirmed at the World Conference on Human Right in Vienna in 1993 as a universal and inalienable right and an integral part of fundamental human rights. The former U.N Commissioner on Human Rights spoke of it as an important right for every human person and all peoples in all countries ${ }^{86}$ and placed emphasis on the individual as the

82 Human Rights and Development/ Human Rights in Relation to... Report of the UN Secretary General, 'In Larger Freedom: Towards Development, Security and Human Rights for all; 2005, available at: http:/ / www.humanright, accessed on 5 April 2014.

83Ibid., note 82.

84 General Assembly Resolution 41/128 of 1986.

${ }^{85}$ Report of UN Secretary General, op. cit., note 76.

86 Resolution 1998/ 72. 
bearer of the right to development. The UN Commission on Human Rights also underlined the importance of structural measures to tackle the problems developing countries have to overcome. In a resolution on the right to development, the Commission, inter alia, stated:

International cooperation acknowledged more than ever as a necessity deriving from reorganised mutual interest, and therefore that such cooperation should be strengthened in order to support efforts of developing countries to solve their social and economic problems and to fulfill their obligations to promote all human rights. ${ }^{87}$

In a resolution on the right to development in 2003, the Commission confirmed the right to development as an inalienable human right and that equality of opportunity for development is a prerogative both of nations and of individuals who make up nations and beneficiary of development.88 It should however, be noted that the states themselves are primarily responsible for development. The international community can contribute to development but cannot take over that responsibility.

An open-ended Working Group of the Right to Development was established in 1998 following a recommendation by the U.N Commission on Human Rights to the ECOSOC. ${ }^{89}$ In its consideration of the $6^{\text {th }}$ report of the independent expert on the right to development, the Working Group discussed what the right to development entails. Accordingly, the realization of the right to development is seen as the fulfillment of a set of claims by people, principally on their State but also on the society at large. It also includes the commitment of the international community to a process that enables them to realize the rights and freedoms set forth in the International Bill of Human Rights. The right to development encompasses the right of the people to the outcome to their process, i.e. improved realization of different human rights, as well as the right to the process of realizing the outcomes itself. It is to be facilitated and ensured by the corresponding duty-bearers on whom the claims are made and who must adopt and implement policies and interventions that conform to the human rights norms, standards and principles. In other words, both the ends and the means to such a process of development are to be treated as a right.

\section{Conclusion and Recommendation}

The rights to development and access to justice have been viewed as a composite right wherein all the rights, i.e. economic, social and cultural, as well as civil and political rights, because of their interdependence and indivisibility, are realized together. The integrity of these rights implies that if any one of them is violated, the composite rights to development and access to justice are also violated. The realization of the right to development has been described in terms of an improvement of a 'vector' of human rights, such that there is improvement of some or at least one of those rights, without any other rights violated. Also, the realization of these right sassumesa process in time, wherein some, if not all, of the desired outcomes are realized progressively, with the element of resource constraints being gradually relaxed through, inter alia, economic growth consistent with human rights norms and principles. ${ }^{90}$

The indivisibility and interdependency of development and human rights has led many organizations to merge the two concepts in their work. The United Nations Development Programme, for instance, has stated that eliminating poverty, sustaining livelihood, promoting gender equality, protecting the environment, and capacity building will assist in mainstreaming human rights in the development sector. The UNDP has concluded that a human rights approach to development will result in a mutually beneficial arrangement of universal human rights and development goals. ${ }^{91}$ Accordingly, it is recommended that access to justice is the most important human right, without which it is impossible to enjoy any other human right. When these rights are made justice able, they will benefit from the rational interpretation, application and rigorous analysis which adjudicatory bodies offer. Through this also, the contents of economic, social and cultural rights will be made clearer, precise and ascertainable. It is further recommended that the National Assembly should enact laws on more of the items provided under chapter two of the Constitution having in mind sections 4(8) and section 13 as well as Item 60(a) of Part I of Schedule 2 to the Constitution. The foregoing provision empowers the legislature to enact laws on any of the items in order to render the ouster clause inoperative and enhance access to justice in the event of breach of ESC rights for any right which cannot be enforced, is no right at all.

\section{References}

i. Nwoha, S.A., Principles of Nigerian Law and Real Practice, Vol. I. (Enugu: John Jacobs Classic Publishers Ltd, (2006) p. 18.

ii. Barton, T., 'Justiciability: 'A Theory of Judicial Problem Solving' Bolston College Law Review, Volume XXIV, May 1993, Number 3, p. 21.

iii. Ladan, M., Introduction to International Human Rights and Humanitarian Laws (Zaria: Ahmadu Bello University Press, 1999) p.71; See also Adamu v. Borno State (1996) 8 [NWLR) 203.

iv. Ladan, M.T., op. cit, note 3 p.71.

\footnotetext{
${ }^{87}$ Resolution 1998/ 72.

88 Resolution 2003/83.

${ }^{89}$ E/ CN.4/ Res/ 1998/ 72.

${ }^{90} \mathrm{E} / \mathrm{CN} .4 / 2004 /$ WG. $18 / 2$.

${ }^{91}$ See the Report of the UN secretary, op. cit., note 76.
} 
v. The Constitution of the Federal Republic of Nigeria, 1999 (as amended), section 46.

vi. Okogie v A.G. Lagos State (1981) I NCLR 218. It was agreed that s. 46(1) permits a plaintiff to commence proceeding if he fears that his right is likely to get trampled upon. See also Omotesho, A.O. and Bawa, A., Issues on Constitutional Law (Lagos: Bold Technology and Systems (Nig.) Ltd, 2001) p. 58.

vii. Garner, B.A., (ed), Black's Law Dictionary, Ninth Edition (Texas: West Publishing Co, 2009) p. 943.

viii. Arambulo, K., Strengthening the Supervision of the International Covenant on Economic, Social and Cultural Rights Theoretical and Procedural Aspect, (Oxford: Intersentia-Hart Antwerp/ Groningen, 1999) p. 55.

ix. Scott, C. and Macklem, P., 'Constitutional Ropes of Sand, or Justiciable Guarantees? Social Rights in a New South African Constitution', University of Pennsyvania Law Review, Vol.141.No.1, November 1992, p. 17.

x. Ibid., note 9, p. 17.

xi. May, C. and Allen, I., Constitutional Law: National Power and Federalism, Fourth edition (New York: Mynas Pen Publishers, 2007) pp. 97-99.

xii. Flast v. Coben, 392 U.S. 83,100 (1968).

xiii. Muskrat v United States, 219 (U.S) 346(1911).

xiv. An unripe question is one for which there is not yet at least a threatened injury to the plaintiff, or where all available judicial alternatives have not been exhausted. A moot question is one for which the potential for an injury to occur has ceased to exist, or where the injury has been removed; Poe v Cullman, 367 U.S 499 (1961; Detunes v Ode Guard 416 U.S. 312,(1974).

xv. Roev Wade, 410 U.S 113(1973).

xvi. Political questions involve matters where there is a textually demonstrable constitutional commitment of the issue to coordinate political department, and the U.S Constitution therefore, requires another branch of government to resolve questions regarding the issue. It also involves a lack of judicially discoverable and manageable standards for resolving issue as well as an impossibility of deciding it without an initial policy determination of a kind clearly for non judicial discretion. Political questions also connote an impossibility of a court undertaking independent resolution without expressing lack of respect due co-ordinate branches of government; an unusual need for unquestioning adhered to a political decision already made; or a potentiality of embarrassment from multifarious pronouncements by various departments on one question. Issues such as whether the nation is at war with another country, or whether the legislature has properly 'tried' an impeached federal officer constitutes a political question. If a case fails to meet any one of these requirements, the court cannot hear it. However, some states permit their courts to give advisory opinions on questions of law, even though there may be no actual dispute to resolve between parties. See also Nixon $\mathrm{v}$ United States, 506 U.S 224 (1993).

xvii. Buttes Gas and Oil Co. v. Hammer (1982) AC 888; McGoldrick, D., The Boundaries of Justiciability', 59 International and Comparative Law Quarterly 981 (2010); See also Martyniszyn, M., (2011) 'Avoidance Techniques: State Related Defences', International Antitrust Cases, Working Paper No. 11-12. See further, Kuwait Airways Co v. Iraqi Airways, (2002) UKHL 19 where the principle was further developed. Case note: Kuwait Airways Corporations v. Iraqi Airways Company; Carothers, J.M. and Crawford, E.B., The International and Comparative Law Quarterly, vol. 52, No 3 (July, 2003), pp. $761-774$.

xviii. Nwoha, S.A., Principles of Nigerian Law and Real Practice, op. cit., note 1, p. 18.

xix. Ibid., note 18.

xx. Ibid. note 19.

xxi. Flast v Cohen, 392 U.S. 83, 888 S.Ct (1942), 20 L.ed 2d 947.

xxii. Ibid., note 21 .

xxiii. Flast v Cohen, 392 U.S. 83, 888 S.Ct (1942), 20 L.ed 2d 947.

xxiv. Warth v Seldin, 422 U.S. 490, 95 S.C.E 2197, 45 led. 2d 343 (1975).

xxv. Doremus v Board of Education, 342 U.S. 429, 72 S.Ct. 394, 96.L. Ed. 475

xxvi. Roe v Wade, 410 U.S 113, 93 S.Ct. 705, 35 L. Ed. $2 d 147$ (1973).

xxvii. Nwabueze, B.O., Judicialism in Common Wealth Africa (London: C. Horst $\beta$ Co, 1977) p.3. See also A.G. Ondo State v A.G Federation (2005) 9 N.W.L.R. (Pt 772) 272-276.

xxviii. Cowley v Cowley (1901) A.C P. 450 (H. L).

xxix. Odike, E.A., Principles and Practice of Nigerian Law, Vol. I (Abakaliki: Willy Rose \& Appleseed Publishing Co., 2009). p. 84.

xxx. Constitution of the Federal Republic of Nigeria, 1999.

xxxi. Ibid., note 30 , section 6 .

xxxii. Wright, C.A., et al, Federal Practice and Procedure, No. 3529, 2nd ed. (1984) pp. 278-279.

xxxiii. Navot, S., 'Political Questions in the Court: Is 'Judicial Self-Restraint' a Better Alternative than a Non-Justiciable Approach?", VII World Congress of the International Association of Constitutional Law Rethink, the Boundaries of Constitutional Law", Workshop: Judicial Review of Politically Sensitive Questions. p. 22.

xxxiv. 369 4.5.186,217 (1962).

xxxv. 506 U.S..224, 229, 236 (1993). 
xxxvi. 413 U.S. 1 (1973).

xxxvii. Valley Forge Christian Coll. v Ams. United for Separation of Church and State, 454 U.S. 464, 472 (1982).

xxxviii. Kontorovich, E., What Starting is Good for: The Doctrine and the Critics', Virginia Law Review, (Vol.93), p.1663.

xxxix. 366 U.S. 420 (1961).

xl. 528 U.S. 167, 180-81 (2000).

xli. 416 U.S. 312 (1974).

xlii. 529 U.S.277 (2000).

xliii. 330 U.S. 75 (1947).

xliv. 387 U.S. 136, 148 (1967), 149.

xlv. Ibid., note 44, p. 149.

xlvi. 2 U.S. (2 Dall.) 409, 411-13 (1792).

xlvii. Fyanka, K.T., 'TheJusticiability of Social Rights: Myth or Reality?' Human Right Review, Vol.1. No.1. (2010), pp. 437444.

xlviii. Fyanka, K.T., op. cit, p. 445.

xlix. Kurland, P.B., 'The Rise and Fall of the Doctrine of Separation of Power', 85 Mich.L.Rev. (1986) pp. 502-593.

l. Fyanka, K.T., op. cit., p. 445.

li. Okpara, O., (ed.), Human Rights Law and Practice in Nigeria, Vol.1 (Enugu: Changlo Limited, 2005) p. 282.

lii. Nwoha, S.A., op. cit., note 1, p. 18.

liii. B.O. Nwabueze, Judicialism in Common Wealth Africa (London: C. Hursy and Co., 1977) p. 3; See also A.G Ondo State v A.G. Federation (2005) 9 N.W.L.R. (pt. 772) 272-276.

liv. Garner, B.A., Black's Law Dictionary, 9th Edition (Texas: West Publishing Co, 2009) p. 943.

lv. Nwoha, S.A., op. cit., Principles of Nigeria Law and Practice, Vol. 1 (Abakaliki: WillyRose\& Appleseed Pub. Coy. 2009) p. 83.

lvi. For example section 6(6)(c) of the Constitution of the Federal Republic of Nigeria as amended, which provides that the powers of the court shall not extend to any issue or question as to whether any act or omission by any authority or person or as to law or any judicial decision is in conformity with the fundamental objective and directive principles of state policy set out under chapter two of the constitution.

lvii. Political question doctrine holds that some questions, in their nature are fundamentally political and legal, and that if a question is fundamentally political, then the court will refuse to hear the case. It will claim that it doesn't have the jurisdiction. And it will leave that question to some other aspect of political process to settle out. See also the US case of Marbury v Madison, 5 U.S 137 (1803).

lviii. 58. Porter, B., Justifiability of ESC Right to Effective Remedies: Historic Challenges and New Opportunities (Beijing: March 32, 2008) p.I, available at: www.socialrights.com/ document, accessed on 24th, August, 2013.

lix. Dennis, I. and Stewart, D.P., 'Justiciability of Economic, Social, and Cultural Rights: Should There be an International Complaints Mechanism to Adjudicate the Rights to Food, Water, Housing, and Health?',American Journal of International Law, 98 A.J.I.L. 462,(July, 2004) p. 6.

lx. AIR 1980 SC1622. The judgment was delivered on 29th July,1980, available at: www.indiankanoon.org/ doc/440471, accessed on 24th August, 2013.

lxi. (1993) 1 SCC 645.

lxii. Supreme Court of Bangladesh Writ No: 3034 of 1999, available at: http://www.right-to-education.org/ node/ 682, accessed on 24th August, 2013.

lxiii. (200) ZACC19, decided on 4, Oct., 2000. In this case, the respondents have been evicted from their informal homes situated on a private land earmarked for low-cost housing. They applied to the High Court for an order requiring the government to provide them adequate basic shelter or housing until they obtain permanent accommodation. The court held that the state was obliged to provide rudimentary shelter to children and their parents on demand if the parents were unable to shelter their children.

lxiv. Suit No. ECW/ CCJ/ APP/ 0808, delivered on 27th Oct, 2009, available online @

lxv. http:/ / www.courts.com.ecowasccj/ eng/ decisions/ 2009.10.27SERAPVNigeria.htm, accessed on 24th August, 2013.

lxvi. The preamble to the African Charter on Human and People's Rights.

lxvii. (2004)AHRLR 205, at 211; (2005) CHR 309, at 323-324; Falana, F., Fundamental Rights Enforcement in Nigeria, Second Edition (Lagos: Legaltext Publishing Company Ltd, 2010) p. 17.

lxviii. Azinge, E. and Owasanoye, B., eds., Rule of Law and Good Governance (Lagos: Nigerian Institute of Advanced Legal Studies, 2009) p. 376. See also 'Access to Justice and Human Rights Protection in Nigeria: Problems and Prospects', in Sur, Rev. Int. Directors Human, Vol.2 No. Sao Paulo Dec. 2005, available at: http:/ / www.scielo.br/ scielo.php?scrip=sciarttext\&piq, accessed 12 August 2014.

lxix. Ladan, M.T., 'Access to Justice and the Justice Sector Reform in Nigeria', a paper presented at the First International Conference on the State of Affairs of Africa, Organized by the International Institute for Justice and Development (IIJD), Boston, Massachusetts, USA. Oct.26-28, 2006, available at: http:/ / iijd.org.PDF\%20files/ MuhamedTawfiqLadan Justice Sector Rector Nigeria,_Pdf, last accessed 11 February 2014. 
lxx. Cappelletti, M. and Garth, R. (eds.), 'Access to Justice: A World Survey' (1978), Vol. 1 Milan, GuilfreEditore, D.A., at 6.

lxxi. Ibid., note 69, p. 6.

lxxii. Nwabueze, B.O., Federalism in Nigeria under the Presidential Constitution, (London: Sweet and Maxwell), p.164.

lxxiii. Quakers, N.I., 'Litigation as Machinery for Political, Economic and Social Reform in Nigeria'. A Paper presented at the Symposium on Public Interest Lawyering organised by Access to Justice on the 7th of August 2009, Available at: http: www.Lexprimus.com.publication,/ accessed on 11/ 02/11.

lxxiv. Udu, E.A., Human Rights in Africa (Lagos: Mbeyi and Associate (Nig.) Ltd., 2011, p. 203.

lxxv. Omotesho, A.O. and Bawa, A.,Issues on Constitutional Law. (Lagos: Bold Technology and Systems (Nig.) Ltd, 2001).

lxxvi. (1971) A.C. 972.

lxxvii. Report of the UN Secretary-General, 'In Larger Freedom: Towards Development, Security and Human Rights for All:2005'.

lxxviii. Steiner, H.J and Alston, P., International Human Rights in Context, (Oxford: Clarendom Press, 1996) p.1110.

lxxix. EIDHR: Democracy, Human Rights and Development, available at: http:// www.eidhr.eu/ democracy-human-right, accessed on 12 June 2014.

lxxx. Caroline v Union Territory of Delhi .I.R. 1981.

lxxxi. Available at: www.ng.undp.org, accessed on 28 October, 2017.

lxxxii. Available at: www.panafrican-med-journal.com, accessed on 28 October 2017.

lxxxiii. Human Rights and Development/ Human Rights in Relation to... Report of the UN Secretary General, 'In Larger Freedom: Towards Development, Security and Human Rights for all; 2005, available at: http://www.humanright, accessed on 5 April 2014.

lxxxiv. Ibid., note 82.,

lxxxv. General Assembly Resolution 41/ 128 of 1986.

lxxxvi. Report of UN Secretary General, op. cit., note 76.

lxxxvii. Resolution 1998/ 72.

lxxxviii. Resolution 1998/ 72.

lxxxix. Resolution 2003/83.

xc. E/ CN.4/ Res/1998/ 72.

xci. E/ CN.4/ 2004/WG. 18/ 2.

xcii. See the Report of the UN secretary, op. cit., note 76 . 